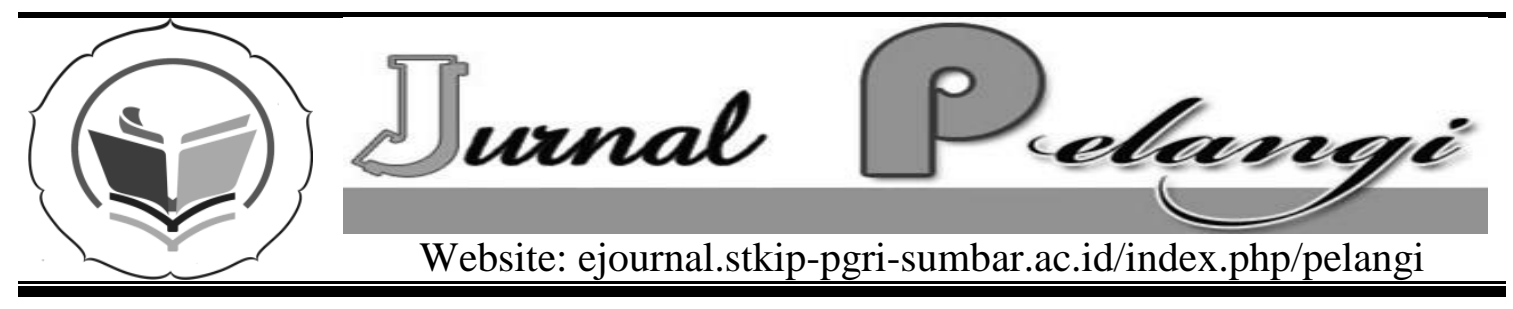

\title{
PENINGKATAN KEGIATAN PEMBELAJARAN TEMATIK TERPADU DENGAN MENGGUNAKAN PENDEKATAN SCIENTIFIC DI KELAS IV SD
}

\author{
Indra Mardi
}

SD Negeri 05 Malabur Kecamatan Ampek Nagari Kabupaten Agam indramardi@yahoo.co.id

\section{INFO ARTIKEL}

\section{Diterima:}

1 Desember 2015

Direview:

9 Desember 2015

Disetujui:

22 Desember 2015

Kata Kunci:

Pembelajaran Tematik Terpadu,

Pendekatan Scientific
Keywords:

Thematic Learning, Scientific Approach

\begin{abstract}
Abstrak
Permasalahan yang dihadapi adalah pembelajaran tematik dengan pendekatan scientific di kelas IV masih menggunakan pendekatan yang lama dimana siswa menerima saja materi pelajaran tanpa menemukan sendiri sehingga mengakibatkan siswa pasif dan tidak serius dalam belajar. Tujuan penelitian ini untuk mendeskripsikan Pembelajaran Tematik Terpadu Dengan Menggunakan Pendekatan Scientific di Kelas IV SD Negeri 05 Malabur Kecamatan Ampek Nagari Kabupaten Agam. Jenis penelitian ini adalah Penelitian Tindakan Kelas (classroom action research). Penelitian ini menggunakan pendekatan kuantitatif sederhana. Data penelitian ini berupa informasi tentang proses dan data hasil tindakan yang diperoleh dari hasil pengamatan, hasil tes. Sumber data adalah proses pelaksanaan Pembelajaran Tematik Terpadu Dengan Menggunakan Pendekatan Scientific di Kelas IV SD Negeri 05 Malabur Kecamatan Ampek Nagari Kabupaten Agam. Subjek penelitian adalah siswa kelas IV yang berjumlah 16 orang. Hasil penelitian yang dianalisis berdasarkan data kualitatif dan kuantitatif, menunjukkan bahwa pada siklus I nilai rata-rata siswa 71.25 dan meningkat pada siklus II dengan nilai rata-rata 88.75 .
\end{abstract}

\section{Abstract}

The background of the research is that the thematic learning using scientific approach in the class IV is still using old approach in which the students only take the materials without finding out by themselves. So that, it makes the students become passive and unfocused during the learning. The purpose of the research is to describe the integrated thematic learning activities by using a scientific approach at class IV Elementary School 05 Malabur Kecamatan Ampek Nagari, Agam Regency. The type of the research is a classroom action 
research. It used a simple quantitative approach. The data were the information about the process, data of action result from observation, and test results. The data source was the implementation process of integrated thematic learning activities by using a scientific approach at class IV Elementary School 05 Malabur Kecamatan Ampek Nagari, Agam Regency. The research subjects were 16 students of class IV students.

The research results analyzed by qualitative and quantitative show that the student's average score in the first cycle is 71.25 and it improves in the second cycle by having an average score i.e. 88.75 .

\section{PENDAHULUAN}

Awal tahun 2013 telah diterbitkan kurikulum baru, dimana pembelajaran di SD disosialisasikan untuk siswa kelas I, II, IV dan, V menggunakan pembelajaran tematik terpadu. Pembelajaran tematik dirancang berdasarkan tema-tema tertentu yang ditinjau dari berbagai mata pelajaran. Pembelajaran tematik merupakan pembelajaran yang menggunakan tema sebagai pemersatu kegiatan pembelajaran yang memadukan beberapa mata pelajaran sekaligus untuk memberikan pengalaman kepada siswa. Depdiknas (2006: 5) menjelaskan bahwa pembelajaran tematik pada dasarnya adalah model pembelajaran terpadu yang menggunakan tema untuk mengaitkan beberapa mata pelajaran sehingga dapat memberikan pengalaman bermakna kepada siswa. Sejalan dengan Trianto (2010: 82) bahwa pembelajaran tematik adalah pembelajaran yang di awali dengan suatu pokok bahasan atau tema tertentu yang dikaitkan dengan pokok bahasan lain, yang dilakukan secara spontan atau direncanakan, baik dalam suatu bidang studi atau lebih dengan beragam pengalaman belajar siswa.
Guru harus mampu menyajikan materi dari berbagai mata pelajaran yang ada secara utuh tidak terpisah-pisah dalam sebuah tema yang telah ditentukan. Dengan penyajian materi secara utuh akan mempermudah siswa untuk memahami materi pembelajaran. Hal ini telah dijelaskan dalam kemendikbud (2013:194) bahwa pada usia sekolah dasar berada pada tahap operasi kongkret. Dengan demikian konsep pembelajaran bisa tertanam dengan baik pemilihan materi yang disajikan harus berkaitan dengan kehidupan sehari-hari siswa dan disesuaikan dengan lingkungan siswa sehingga siswa akan lebih mudah mengerti dan proses belajar mengajar akan lebih menyenangkan dan dapat diaplikasikan oleh siswa didalam lingkungannya.

Berdasarkan observasi yang dilakukan di kelas IV SDN 05 Malabur Kecamatan Ampek Nagari, dalam melaksanakan proses pembelajaran terlihat hasil belajar siswa rendah disebabkan: 1) Pada Kurikulum 2013 guru dituntut menggunakan Tema sebagai pengikat pembelajaran untuk semua mata pelajaran, akan tetapi guru di dalam kegiatan proses pembelajaran 


\section{Jurnal Pelangi}

selalu memberikan pelajaran per masing -masing bidang studi. 2) Pada Kurikulum 2013 menuntun siswa untuk mencari tahu, akan tetapi di setiap pembelajaran guru yang berperan aktif di dalam pembelajaran tersebut karena siswa malas atau kurang memahami maksud dan arahan dari guru. 3) Di dalam pembelajaran guru kurang memahami penilaian yang akan di berikan, karena itu di dalam kegiatan pembelajaran guru sering tidak melaksanakan penilaian. 4) Guru kurang paham cara membuat penilaian yang akan dicantumkan ke dalam rapor siswa.

5) Sering siswa terabaikan karena terlalu banyaknya tugas guru. 6) Kurangnya guru mengajak siswa mengamati suatu objek di dalam kegiatan proses pembelajaran. 7) Guru kurang melatih siswa, untuk mengajukan pertanyaan. 8) Siswa tidak dilatih di dalam mengosiasi/mengolah informasi, menalar dengan cara memproses informasi yang sudah dikumpulkan dari hasil kegiatan mengamati. 9) Guru kurang melakukan sebuah percobaan kepada siswa. 10) Guru kurang melatih siswa di dalam kegiatan pembelajaran untuk mengkomunikasikan hasil percobaan.

Hasil lain menunjukan bahwa dengan kurang mengertinya guru tentang pembelajaran tematik mempunyai dampak proses pembelajaran siswa. Siswa masih bersikap pasif saat proses pembelajaran berlangsung, siswa lebih banyak duduk diam di tempat dan mendengarkan guru yang sedang mendengarkan materi. Kurang aktifnya siswa dalam proses pembelajaran mengakibatkan hasil belajar siswa pada proses pembelajaran.
Analisis observasi hal tersebut disebabkan oleh guru yang kurang menggunakan pendekatan, model atau metode pembelajaran yang cocok dengan pembelajaran tematik, sehingga membuat pembelajaran hanya berpusat pada guru, pembelajaran tidak memberikan kesempatan kepada siswa untuk mengasimilasi dan mengakomodasikan konsep, hukum, dan prinsip, pembelajaran kurang mendorong terjadinya peningkatan kemampuan berfikir siswa, kurang memberikan kesempatan kepada siswa untuk melatih kemampuan dalam komunikasi.

Untuk mengatasi kondisi di atas perlu diadakan pembaharuan salah satunya adalah menggunakan pendekatan Scientific. Kemendikbud (2013:2) mengungkapkan bahwa "Pembelajaran berbasis pendekatan Scientific lebih efektif hasilnya dibandingkan dengan pembelajaran tradisional." Varelas and Fored (2008:31) mengungkapkan bahwa "Pendekatan ini memudahkan guru atau pengembang kurikulum untuk memperbaiki proses pembelajaran, yaitu dengan memecah proses ke dalam langkah-langkah atau tahapan-tahapan secara terperinci yang memuat instruksi untuk siswa melaksanakan kegiatan pembelajaran."

Berdasarkan uraian yang dikemukakan di atas, Penelitian ini bertujuan untuk mengetahui bagaimana perbaikan Pembelajaran Tematik Terpadu Dengan Menggunakan Pendekatan Scientific di Kelas IV SD Negeri 05 Malabur Kecamatan Ampek Nagari Kab. Agam. 
Pembelajaran pada hakekatnya adalah suatu proses interaksi antar siswa dengan siswa, siswa dengan sumber belajar dan siswa dengan pendidik. Kegiatan pembelajaran ini akan menjadi bermakna bagi siswa jika dilakukan dalam lingkungan yang nyaman dan memberikan rasa aman bagi siswa. Proses belajar bersifat individual dan kontekstual, artinya proses belajar terjadi dalam diri individu sesuai dengan perkembangan dan lingkungan siswa.

Ujang sukandi dalam Trianto (2010:83) mengatakan "Pembelajaran tematik sebagai kegiatan mengajar dengan memadukan materi beberapa mata pelajaran dalam satu tema" Dari penjelasan di atas dapat di simpulkan bahwa pembelajaran tematik adalah pembelajaran terpadu yang menggunakan pedekatan tematik yang melibatkan beberapa mata pelajaran untuk memberikan pengalaman yang bermakna kepada siswa. Fokus yang di tempuh siswa saat berusaha memahmi isi pembelajaran sejalan dengan bentukbentuk keterampilan yang harus di kembangkan.

Menurut Papas (1990: 105) dan Karli (2006: 95) pembelajaran pada kelas awal Sekolah Dasar (SD) lebih sesuai jika di kelola melalui pendekatan tematik, karena pada umumnya dalam tahap ini siswa melihat segala sesuatu itu sebagai kesatuan yang utuh (holistik). Dari pendapat di atas yang dimaksud dengan pendekatan tematik adalah: suatu pendekatan pembelajaran yang beranjak dari suatu tema untuk mengaitkan beberapa mata pelajaran tertentu dan konsep yang lain secara spontan atau direncanakan dengan memberikan pengalaman bermakna kepada siswa, sehingga siswa dapat belajar dengan aktif dan efesien.

$$
\text { Depdiknas dalam Rusman }
$$

(2010:258) menjelaskan bahwa manfaat pembelajaran tematik adalah: (a) Menghubungkan beberapa kompetensi dasar dan indikator serta isi mata pelajaran akan terjadi penhematan, karena tumpang tindih materi dapat di kurangi bahkan dapat di hilangkan, (b) peserta didik mampu melihat hubungan yang bermakna antar mata pelajaran, (c) pelajaran menjadi utuh sehingga peserta didik akan mendapatkan pengertian mengenai proses dan materi pelajaran yang tidah terpisah-pisah, (d) adanya pemanduan antara mata pelajaran maka penguasaan konsep semakin baik dan meningkat.

Sebagai suatu proses, pembelajaran tematik memiliki karakteristikkarakteristik tematik. Menurut Depdiknas (2006: 98) karakteristik tematik adalah: 1) Berpusat kepada siswa; 2) Memberikan pengalaman langsung; 3) Pemisahan mata pelajaran tidak begitu jelas; 4) Menyajikan konsep dari berbagai mata pelajaran; 5) Bersifat fleksibel; 6) Hasil pembelajaran sesuai dengan minat dan kebutuhan siswa; 7) Menggunakan prinsip belajar sambil bermain dan menyenangkan.

Kelebihan-kelebihan pendekatan tematik menurut Tim Pengembangan PGSD (1996/1997:7) diantaranya: 1) Pengalaman dan belajar siswa relevan dengan tingkat perkembangan siswa; 2) Kegiatan dipilih sesuai minat dan kebutuhan siswa; 3) Seluruh pembelajaran akan dapat bertahan lebih lama; 4) Pembelajaran tematik 
menumbuh kembangkan keterampilan berfikir siswa; 5) Menyajikan kegiatan yang bersifat pragmatis sesuai dengan permasalahan yang sering ditemui dalam lingkungan siswa; 6) Menumbuh kembangkan keterampilan sosial siswa, bekerja sama, toleransi, komunikasi, dan tanggap terhadap orang lain.

Pendekatan pembelajaran merupakan suatu usaha atau cara menyikapi untuk mengembangkan keefektifan pembelajaran. Rusman (2009: 193) mengungkapkan bahwa "Pendekatan pembelajaran dapat diartikan sebagai titik tolak atau sudut pandang kita terhadap proses pembelajaran". Sedangkan Jihad (2008: 24) mengatakan bahwa "Pendekatan pembelajaran adalah suatu jalan, cara, atau kebijaksanaan yang ditempuh oleh guru juga siswa untuk mencapai tujuan pembelajaran apabila kita melihatnya dari sudut bagaimana proses pembelajaran atau materi pembelajaran itu dikelola".

Pendekatan Scientific dipakai sebagai penekanan pada metode laboratorium formalistik yang mengarah pada fakta-fakta ilmiah. (Hudson, 1996:3). Pendekatan Scientific ini memiliki karakteristik "doing science". "Pendekatan ini memudahkan guru atau pengembang kurikulum untuk memperbaiki proses pembelajaran, yaitu dengan memecah proses ke dalam langkah-langkah atau tahapan-tahapan secara terperinci yang memuat instruksi untuk siswa melaksanakan kegiatan pembelajaran."Varelas and Ford (2008: 31).

Menurut Lazim (2013:1) "Pendekatan Scientific diartikan sebagai aktivitas pembelajaran yang dirancang sedemikian rupa agar peserta didik secara aktif mengonstruksi konsep, hukum atau prinsip melalui tahapantahapannya." Lebih lanjut Kemendikbud (2013:3) menegaskan Pendekatan Scientifik merupakan "Perpaduan antara proses pembelajaran yang semula terfokus pada eksplorasi, elaborasi, dan konfirmasi dilengkapi dengan mengamati, menanya, menalar, mencoba, dan mengkomunikasikan".

Pendekatan Scientific meliputi suatu pembelajaran yang dirancang sedemikian rupa agar peserta didik secara aktif mengkonstruksi konsep ,hukum, atau prinsip melalui tahapantahapannya. Menurut Lazim (2013:2) tujuan pendekatan Scientific adalah: (1) Meningkatkan kemampuan intelek, khususnya kemampuan berfikir tingkat tinggi siswa, (2) Membentuk kemampuan siswa dalam menyelesaikan suatu masalah secara sistematik, (3) Terciptanya kondisi pembelajaran dimana siswa merasa bahwa belajar itu merupakan suatu kebutuhan, Diperolehnya hasil belajar yang tinggi, (5) Melatih siswa dalam mengkomunikasikan ide-ide, khususnya dalam menulis artikel ilmiah, (6) Mengembangkan karaktek siswa.

Pendekatan Scientific bertujuan agar dapat merangsang kemampuan berfikir siswa untuk. memecahkan masalah serta belajar mandiri dalam memecah permasahan di kehidupan mereka dan mengkomunikasikan ide-ide dalam pembelajaran. Pendekatan Scientific merupakan aktvitas pembelajaran yang menekankan kepada proses penyelesaian masalah yang dihadapi secara ilmiah dan 
bertujuan untuk membantu siswa belajar secara mandiri. Oleh karena itu, karakteristik umum yang harus dimiliki Pendekatan Scientific menurut Lazim (2013:1) yaitu: (1) Pembelajaran berpusat pada siswa, (2) pembelajaran membentuk student self concept, (3) pembelajaran terhindar dari verbalisme, (4) pembelajaran memberi kesempatan kepada siswa untuk mngasimiliasi dan mengakomodasikan konsep, hukum, dan prinsip, (5) pembelajaran mendorong terjadinya peningkatan kemapuan berfikir siswa, (6) pembelajaran meningkatkan motovasi belajar siswa dan memotivasi belajar guru, (7) memberikan kesempatan kepada siswa untuk melatih melatih kemampuan dalam komunikasi, (8) adanya proses validasi terhadap konsep, hukum, dan prinsip yang dikonstruksi siswa dalam struktur kognitifnya.

Kemendikbud (2013:6) merangkum karakteristik yang tercakup dalam Pendekatan Scientific adalah: (1) Substansi atau materi pembelajaran berbasis pada fakta atau fenomena yang dapat dijelaskan dengan logika atau penalaran tertentu; bukan sebatas kirakira, khayalan, legenda, atau dongeng semata, (2) Penjelasan guru, respon peserta didik, dan interaksi edukatif guru-peserta didik terbebas dari prasangka yang serta-merta, pemikiran subjektif, atau penalaran yang menyimpang dari alur berpikir logis, (3) Mendorong dan menginspirasi peserta didik berpikir secara kritis, analistis, dan tepat dalam mengidentifikasi, memahami, memecahkan masalah, dan mengaplikasikan substansi atau materi pembelajaran, (4) Mendorong dan menginspirasi peserta didik mampu berpikir hipotetik dalam melihat perbedaan, kesamaan, dan tautan satu sama lain dari substansi atau materi pembelajaran, (5) Mendorong dan menginspirasi peserta didik mampu memahami, menerapkan, dan mengembangkan pola berpikir yang rasional dan objektif dalam merespon substansi atau materi pembelajaran, (6) Berbasis pada konsep, teori, dan fakta empiris yang dapat dipertanggungjawabkan, (7) Tujuan pembelajaran dirumuskan secara sederhana dan jelas, namun menarik sistem penyajiannya.

Menurut Depdiknas dalam diklat guru (2013) "Pendekatan Scientific terdiri dari 5 langkah yaitu: "1) Mengamati (Observing), 2) Menanya (Questioning), 3) Menalar (Associating), 4) Mencoba (Eksperimenting), 5) Mengkomunikasikan (Networking).

Kegiatan pembelajaran dengan menggunakan Scientific terdiri dari lima langkah yaitu:

1) Mengamati (Observing). Pada langkah ini, kegiatan pembelajaran dimulai dengan mengamati Guru menenentukan objek apa yang akan diamati, objek yang diamati secara nyata. Guru menampilkan sebuah media dan diperlihatkan pada siswa, lalu siswa mengomentari media tersebut. Kegiatan mengamati sangat bermanfaat bagi pemenuhan rasa ingin tahu siswa sehingga proses pembelajaran memliki kebermaknaan yang tinggi.

2) Menanya (Questioning). Pada langkah ini siswa dibimbing untuk dapat mengajukan pertanyaanpertanyaan berdasarkan hasil 
pengamatan. Berdasrkan media yg di tampilkan siswa saling bergantian bertanya tentang media tersebut. Guru harus mampu menginprasi peserta didik untuk meningkatkan dan mengembangkan ranah sikap, keterampilan dan pengetahuannya. Pada saat guru bertanya, pada saat itu pula dia membimbing atau memandu peserta didiknya belajar dengan baik, ketika guru menjawab pertanyaan peserta didiknya ketika itu pula dia mendorong asuhannya itu untuk menjadi penyimak dan pembelajaran yang baik

3) Menalar (Associating). Pada langkah ini, siswa mengosiasi/mengolah informasi, menalar dengan cara memproses informasi yang sudah dikumpulkan baik dari hasil kegiatan mengamati dan ,setelah menemukan keterkaitan tersebut, selanjutnya secara bersama-sama siswa dalam satu kesatuan kelompok, mencari suatu kesimpulan dari media yang mereka amati tersebut dan secara bersama kelompok membuat kesimpulan.

4) Mengasosiasikan ( Eksperimenting). Pada langkah ini siswa dituntun melakukan sebuah percobaan, peserta didik harus mencoba atau melakukan percobaa, tertaman untuk materi atau substansi yang sesuai. Dalam hal ini siswa di minta mencertakan wilayah tempat tinggak mereka jenis jenis pekerjaan apa saja yang ada. Aplikasi metode eksperimen atau mencoba, di maksudkan untuk mengembangkan berbagai ranah tujuan belajar, yaitu sikap, keterampilan dan pengetahuan.
5) Mengkomunikasikan (Networking). Pada langkah ini peserta didik diarahkan untuk mengkomunikasikan hasil percobaan yang ditemukan peserta didik dalam diskusi kelompok. Kemudian salah satu anggota kelompok menyampaikan jenis jens pekerjaan yang ada di sekttr lingkunganya, dan pada saat diskusi ke depan kelas dan kelompok lain menanggapi.

\section{METODE PENELITIAN}

Subjek dalam penelitian adalah guru dan siswa di kelas IV SD Negeri 05 Malabur Kecamatan Ampek Nagari Kabupaten Agam yang berjumlah 16 orang. Dengan jumlah 9 siswa laki-laki dan 7 siswa perempuan. Penelitian tindakan kelas ini pelaksanaanya dilakukan pada semester I pada tahun ajaran 2014/2015.

Jenis penelitian ini adalah penelitian tindakan kelas yang berkenaan dengan perbaikan atau peningkatan proses pembelajaran pada suatu kelas. Oleh sebab itu, penelitian yang dilaksanakan berasal dari persoalan praktek pembelajaran di kelas secara lebih profesional. Dalam penelitian ini digunakan penelitian tindakan kelas Kemmis \& Taggart, dkk (dalam Hermawan, dkk, 2007:127) yaitu: Proses penelitian tindakan merupakan daur ulang atau siklus yang dimulai dari aspek mengembangkan perencanaan melakukan tindakan sesuai rencana, melakukan observasi terhadap tindakan dan melakukan refleksi yaitu perenungan terhadap perencanaan. Kegiatan tindakan dan kesuksesan hasil yang diperoleh sesuai dengan prinsip umum penelitian 
tindakan setiap tahapan dan siklusnya selalu secara partisipatoris dan kolaboratif antara penelitian dan praktisi (guru dan kepala sekolah) dalam sistem persekolahan.

Model siklus ini mempunyai empat komponen yaitu perencanaan, tindakan, pengamatan dan refleksi. Penelitian ini dilaksanakan dengan dua siklus yaitu siklus pertama dan kedua. Setiap siklus dilaksanakan dua kali pertemuan.Pada setiap pertemuan dilakukan pengamatan terhadap aktifitas guru dan siswa selama proses belajar mengajar yaitu selama $2 \times 35$ menit, setelah akhir setiap siklus dilakukan tes hasil belajar.

\section{Studi Pendahuluan}

Kegiatan studi pendahuluan berupa observasi awal yang dilakukan terhadap guru dalam proses pembelajaran tematik yang dilaksanakan selama ini di kelas IV SD Negeri 05 Malabur Kecamatan Ampek Nagari Kabupaten Agam. Dari studi pendahuluan diidentifikasi masalah pembelajaran tema 4 berbagai pekerjaan di kelas IV SD Negeri 05 Malabur Kecamatan Ampek Nagari Kabupaten Agam. Berdasarkan hasil observasi dan wawancara dengan guru diperoleh kesimpulan bahwa guru masih jarang menggunakan pendekatan yang sesuai dalam pembelajaran tematik.

\section{Perencanaan Tindakan}

Sesuai dengan rumusan masalah hasil studi pendahuluan, dibuat rencana tindakan yang akan dilakukan. Kegiatan itu dimulai dengan merumuskan rancangan tindakan pembelajaran tentang tema, dan sub tema pembelajaran yaitu dengan kegiatan berikut:
1) Menyusun rancangan tindakan berupa rencana pelaksanaan pembelajaran (RPP) yang sesuai dengan tahapan pembelajaran model pembelajaran tematik. Hal ini meliputi: kompetensi inti, kompetensi dasar, tujuan pembelajaran, memilih dan menetapkan materi, pelaksanaan proses pembelajaran, memilih media, dan menetapkan evaluasi.

2) Menyusun alat perekam data berupa tes, lembar observasi

3) Menyusun indikator deskriptor dan kriteria penilaian melalui pendekatan Scientific.

\section{Pelaksanaan}

Pelaksanaan pembelajaran tematik tema, subtema, pembelajaran, dengan penerapan pendekatan Scientific sesuai dengan perencanaan. Penelitian ini dilaksanakan dalam dua siklus.

Setiap siklus mempunyai kompetensi inti yang sama dengan topik yang berlainan sesuai dengan rencana pembelajaran yang telah disusun. Kegiatan ini dilakukan oleh peneliti sebagai praktisi dan guru kelas sebagai observer. Praktisi melaksanakan kegiatan pembelajaran di kelas berupa kegiatan interaksi antara guru dengan siswa dengan siswa. Kegiatan yang dilakukan seperti kegiatan berikut ini:

1) Peneliti atau praktisi melaksanakan pembelajaran dengan penerapan model pembelajaran sesuai rancangan pembelajaran yang dibuat.

2) Guru melakukan pengamatan dengan menggunakan lembar observasi. 
3) Peneliti dan guru kelas melakukan diskusi terhadap tindakan yang dilakukan, kemudian melakukan refleksi. Hasilnya dimanfaatkan untuk perbaikan atau penyempurnaan selanjutnya.

\section{Pengamatan}

Pengamatan terhadap tindakan pembelajaran tematik di kelas IV dengan Pendekatan Scientific dilakukan bersamaan dengan pelaksanaan tindakan. Hal ini dilakukan secara intensif, objektif dan sistematis .Pengamatan dilakukan guru pada waktu penulis melaksanakan tindakan pembelajaran tematik.

Dalam kegiatan ini direkam dan didokumentasikan semua indikator dari proses hasil perubahan yang terjadi baik yang disebabkan oleh tindakan terencana maupun dampak interverensi dalam pembelajaran tematik berdasarkan Pendekatan Scientific. Keseluruhan hasil pengamatan direkam dalam bentuk lembar observasi.

Pengamatan dilakukan secara terus menerus mulai dari siklus I sampai dengan siklus II. Pengamatan yang dilakukan pada siklus dapat mempengaruhi penyusunan tindakan pada siklus selanjutnya. Hasil pengamatan ini kemudian didiskusikan dengan guru dan diadakan refleksi untuk perencanaan siklus berikutnya.

\section{Refleksi}

Refleksi diadakan setiap satu kali tindakan berakhir. Pada kegiatan ini penulis dan guru mengamati lembaran observasi yang telah dilakukan serta melakukan diskusi tentang kelebihan dan kekurangan yang terdapat pada pembelajaran yang telah dilakukan. Apabila terdapat kekurangan maka dilakukan perbaikan terhadap kegiatan pembelajaran. Selain itu guru dan penulis mengulas dan menjelaskan perbedaan rencana dan pelaksanaan tindakan yang telah dilakukan. Lalu melakukan intervensi, pemaknaan dan penyimpulan data yang diperoleh. Hasil refleksi bersama ini dimanfaatkan sebagai masukan pada tindakan selanjutnya .Selain itu, hasil kegiatan refleksi setiap tindakan digunakan untuk menyusun simpulan terhadap hasil tindakan I dan II.

Pengumpulan data penelitian dilakukan melalui teknik observasi, wawancara, dan dokumentasi. Observer mendokumentasikan semua indikator proses hasil dari perubahan yang terjadi. Keseluruhan hasil pengamatan di lakukan terus-menerus dari siklus I sampai siklus II. Kelemahan yang di temui pada siklus I diperbaiki pada siklus II. Kelemahan yang d temaui pada siklus I diperbaiki kembali untuk perencanaa siklus II.

Instrumen Penelitan yang digunakan adalah Lembar Instrumen Penilaian Kemampuan Guru (IPKG). Lembar ini digunakan untuk mengamati rencana pelaksanaan pembelajaran yang berhubungan dengan RPP yang sesuai dengan pendekatan scientific. Lembar observasi, berupa lembaran pengamatan yang disediakan untuk mengamati proses penggunaan pendekatan scientific untuk meningkatkan proses pembelajaran tematik terpadu.

Catatan lapangan, berisi berbagai aspek dalam pembelajaran di kelas suasana kelas, pengoelolan kelas, 
hubungan guru dengan siswa serta interaksi siswa dengan siswa. Catatn lapangan memuat secara deskriptif berbagai kegiatan, suasana kelas iklim sekolah dan nuansa-nuansa lainnya.

Data yang diperoleh dalam penelitian dianalisis dengan menggunakan analisis data kualitatif yang ditawarkan oleh Miles dan Huberman ( dalam Kunandar 2008:101 ) yang diuraikan sebagai berikut:

1. Menelaah data yang terkumpul baik melalui observasi, pencatatan, dengan melakukan proses transkripsi hasil pengamatan, penelitian dan pemilahan data. Seperti mengelompokkan data pada siklus I, II dan seterusnya. Kegiatan menelaah data dilaksanakan sejak awal data dikumpulkan.

2. Reduksi data meliputi kategorian dan pengklasifikasian. Semua data yang terkumpul diseleksi dan dikelompokkan sesuai dengan fokus. Data yang telah dipisah-pisahkan tersebut lalu diseleksi mana yang data yang relevan dan tidak relevan untuk dianalisis.

3. Menyajikan data dilakukan dengan cara mengorganisasikan informasi yang sudah direduksi. Data tersebut mula-mula disajikan terpisah, tetapi setelah tindakan terakhir direduksi, keseluruhan data tindakan dirangkum dan disajikan secara terpadu sehingga diperoleh sajian tunggal berdasarkan fokus pembelajaran tematik menggunakan pendekatan Scientific.

4. Mengumpulkan hasil penelitian, tindakan ini merupakan penyimpulan akhir penelitian. Kegiatan dilakukan dengan cara: a) peninjauan kembali pengamatan yang di lakukan, b) bertukar pikiran dengan ahli, teman sejawat, guru, serta kepala sekolah.

Data kuantitatif yakni data hasil belajar siswa dianalisis dengan menggunakan pendekatan kuantitatif yang dikemukakan oleh Purwanto (2007:112) dengan rumus sebagai berikut:

$\mathrm{NP}=\frac{R}{S M} \times 100$

Keterangan:

$\mathrm{NP}=$ Nilai yang diharapkan (dicari)

$\mathrm{R}=$ Jumlah skor yang diperoleh

$\mathrm{SM}=$ Jumlah skor maksimal

Nilai hasil belajar yang dimaksud adalah nilai hasil belajar yang mencakup tiga ranah, yaitu ranah kognitif, afektif dan psikomotor. Kriteria keberhasilan belajar menurut Rusliana (2007):

$$
\begin{array}{ll}
90 \%-100 \% & =\text { Sangat Baik } \\
80 \%-89 \% & =\text { Baik } \\
70 \%-79 \% & =\text { Cukup } \\
\leq 69 \% & =\text { Kurang }
\end{array}
$$

\section{HASIL DAN PEMBAHASAN}

\section{Siklus I}

Penggunaan pendekatan dalam pembelajaran tematik terpadu dalam bentuk rencana pelaksanaan (RPP), rencana disusun untuk satu kali pertemuan yaitu 6x35 menit. Rencana pembelajaran disusun dan dikembangkan berdasarkan kurikulum 2013 semester I. Rencana pembelajaran disusun dan dikembangkan berdasarkan kurikulum 2013 dengan KD dan Indikator sebagai berikut: 


\section{B.INDONESIA}

1. Mengakui dan mensyukuri anugerah Tuhan yang Maha Esa atas keberadaan lingkungan dan sumber daya alam, alat teknologi modern dan tradisional, perkembangan teknologi, sosial, serta permasalahan sosial

2. Memiliki kepedulian terhadap lingkungan dan sumber daya alam melalui pemanfaatan bahasa Indonesia

3. Menggali informasi dari teks cerita petualangan tentang lingkungan dan sumber daya alam dengan bantuan guru dan teman dalam bahasa Indonesia lisan dan tulis dengan memilih dan memilah kosakata baku

4. Menyajikan teks cerita petualangan tentang lingkungan dan sumber daya alam secara mandiri dalam teks bahasa Indonesia lisan dan tulis dengan memilih dan memilah kosakata baku

\section{Indikator:}

1. Menemukan informasi tentang teh dan proses pembuatannya melalui kegiatan membaca

2. Menyajikan cerita singkat tentang proses pembuatan teh setelah kegiatan membaca

\section{IPS}

1. Menjalankan ajaran agama dalam berpikir dan berperilaku sebagai penduduk Indonesia dengan mempertimbangkan kelembagaan sosial, budaya, ekonomi, dan politik dalam masyarakat

2. Menunjukkan perilaku santun, toleran dan peduli dalam melakukan interaksi sosial dengan lingkungan dan teman sebaya

3. Memahami manusia dalam dinamika interaksi dengan lingkungan alam, sosial, budaya, dan ekonomi

4. Menceritakan manusia dalam dinamika interaksi dengan lingkungan alam, sosial, budaya,dan ekonomi

\section{Indikator}

1. Mengidentifikasi jenis-jenis pekerjaan berdasarkan kondisi geografis daerah tepat tinggal

2. Menjelaskan hubungan jenis-jenis pekerjaan dengan kondisi geografis lingkungan tempat tinggal melalui kegiatan membaca peta

\section{IPA}

1. Bertambah keimanannya dengan menyadari hubungan keteraturan dan kompleksitas alam dan jagad raya terhadap kebesaran Tuhan yang menciptakannya, serta mewujudkannya dalam pengamalan ajaran agama yang dianutnya

2. Menunjukkan perilaku ilmiah (memiliki rasa ingin tahu, objektif,jujur, teliti, cermat, tekun, hati-hati, bertanggung jawab, terbuka, dan peduli lingkungan) dalam aktivitas sehari-hari sebagai wujud implementasi sikap dalam melakukan inkuiri ilmiah dan berdiskusi

3. Mendeskripsikan hubungan antara sumber daya alam dengan lingkungan, teknologi, dan masyarakat

4. Menyajikan laporan hasil pengamatan tentang teknologi yang digunakan di kehidupan seharihari 
dan kemudahan yang diperoleh oleh masyarakat dengan memanfaatkan teknologi tersebut

\section{Indikator:}

1. Menjelaskan sumber daya alam di suatu daerah dan menghubungkannya dengan jenisjenis pekerjaan yang ada

2. Menyajikan laporan hasil pengamatan

\section{Tujuan Pembelajaran}

1. Dengan mengkaji bacaan tentang hubungan sumber daya alam dan pekerjaannya, siswa mampu menjelaskan hubungan sumber daya alam dan pekerjaan yang ada di daerah tersebut dengan teliti.

2. Dengan kegiatan membaca dan menganalisa bacaan, siswa mampu menemukan informasi tentang teh, jenis pekerjaan dan proses pembuatannya dengan benar.

3. Dengan kegiatan membaca peta, siswa mampu mejelaskan hubungan antara beberapa jenis pekerjaan dengan kondisi geografis daerah tempat tinggal secara benar.

4. Dengan mengamati gambar dan berdiskusi, siswa mampu menjelaskan hubungan antara sumber daya alam dan kondisi geografis (dataran rendah, tinggi dan perairan).

5. Dengan membaca teks petualangan "Ulil Si Daun Teh", siswa mampu menjelaskan proses daun teh menjadi teh tubruk secara runtut.

6. Dengan penjelasan guru siswa mampu menyajikan laporan hasil pengamatan dengan tepat
Untuk mencapai tujuan tersebut, rencana pelaksanaan pembelajaran untuk setiap pertemuan dibagi menjadi tiga tahap yaitu kegiatan awal, kegiatan inti, dan kegiatan akhir. Di mana ke tiga kegiatan ini saling terkait satu sama lain.

Pengamatan terhadap tindakan pembelajaran tema dilakukan bersamaan dengan pelaksanaan tindakan. Hal ini dilaksanakan secara intensif, objektif, dan sistimatis. Pengamatan akan dilakukan oleh teman sejawat selaku obsever pada waktu peneliti melaksanakan tindakan pembelajaran tematik dengan pendekatan Scientific.

Dalam kegiatan ini peneliti dan teman sejawat berusaha mengenal, dan mendokumentasikan semua indikator dari proses hasil perubahan yang telah terjadi, baik yang disebabkan oleh tindakan terencana maupun intervensi dalam pembelajaran. Keseluruhan hasil pengamatan ditulis dalam lembar observasi.

Pengamatan yang dilakukan pada satu siklus dapat mempengaruhi penyusunan tindakan pada siklus selanjutnya. Hasil pengamatan ini kemudian didiskusikan dengan teman sejawat dan diadakan refleksi untuk perencanaan siklus berikutnya. Obsever mengevakuasi sejauh mana tindakan yang telah dilakukan dalam memecahkan masalah dengan melihat:

1. Menyusun langkah-langkah perbaikan pembelajaran.

2. Menentukan alokasi wakktu dalam perbaikan pembelajaran

3. Menggunakan bahan atau media perbaikan pembelajaran dan merumuskan tujuan pembelajaran 
4. Menentukan cara pengorganisasian siswa agar siswa dapat berpartisipasi dalam perbaikan pembelajaran

5. Melaksanakan pembelajaran yang sesuai dengan tujuan, siswa, situasi dan lingkungan

6. Melaksanakan perbaikan secara individual

7. Memberi petunjuk dan penjelasan yang berkaitan dengan pembelajaran
8. Mendemontrasikan penguasaan materi

9. Mengembangkan siswa untuk berkomunikasi dan bernalar

10. Melaksanakan penilaian selama proses pembelajaran

11. Melaksanakan penilaian pada akhir pembelajaran

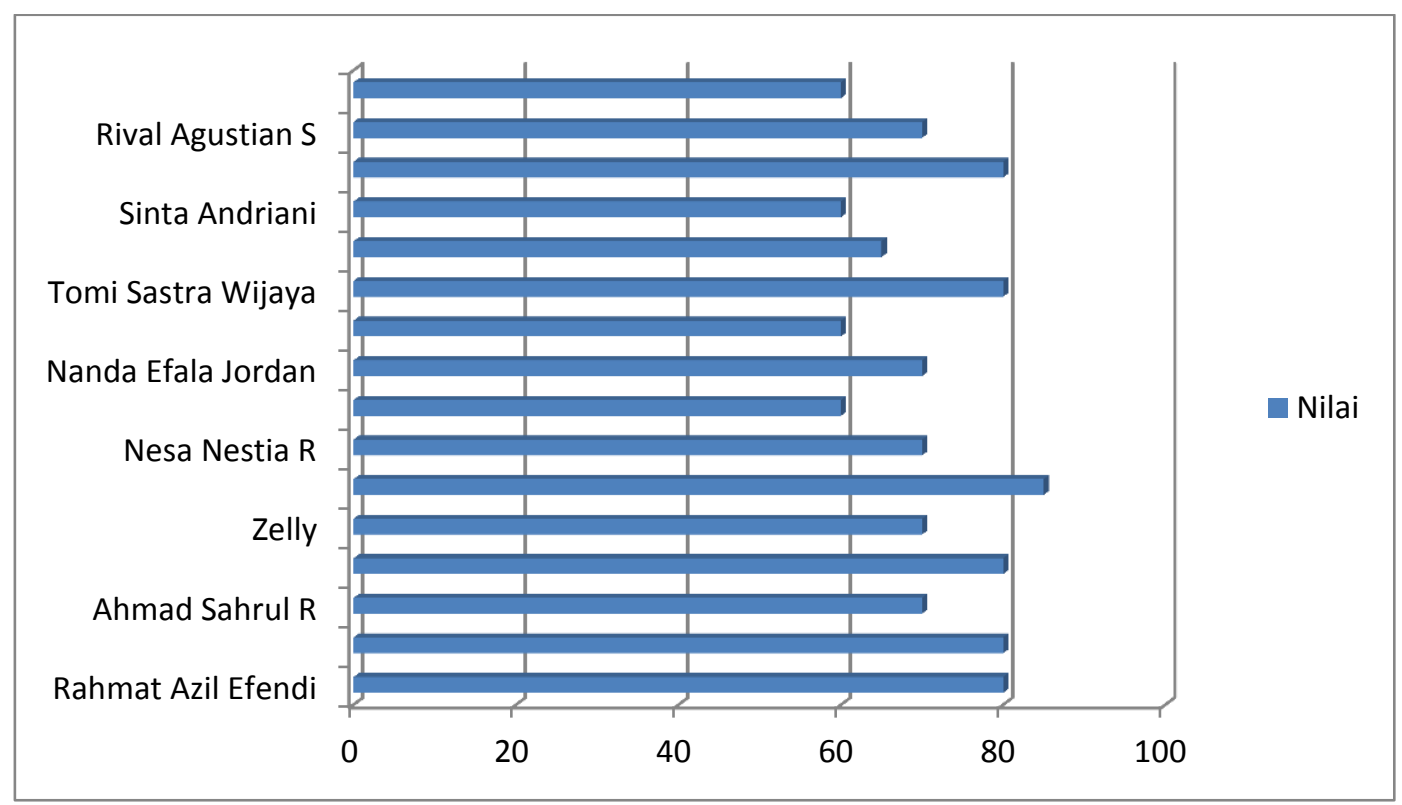

Grafik 1. Hasil Belajar Siswa Siklus I

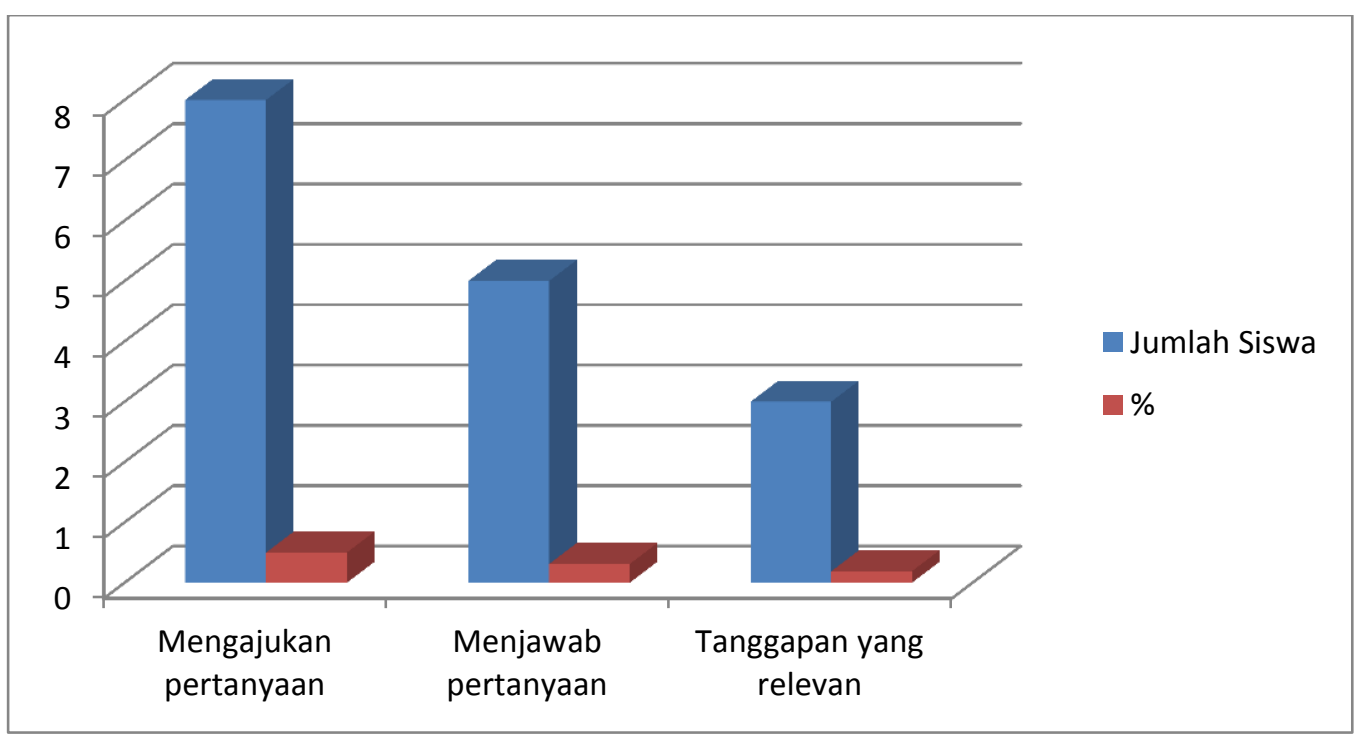

Grafik 2 Aktivitas Belajar Siswa Pada Siklus 
Berdasarkan pengamatan dan catatan pelaksanaan kegiatan pembelajaran pada siklus I dapat digambarkan hasil tes proses dan tes akhir. Dari tabel 1 dapat dilihat bahwa pemahaman konsep belajar, siswa kurang aktif baik mengajukan pertanyaan, menjawab pertanyaan dan memberikan tanggapan. Pengamatan yang dilakukan terhadap guru yaitu penggunaan waktu yang belum efisien serta cara siswa menguasai materi yang diajarkan masih terbilang lemah.

\section{Refleksi}

Berdasarkan proses pembelajaran yang dilakukan bahwa tujuan pembelajaran yang diinginkan belum tercapai. Guru sebagai fasilitator belum mampu membuat siswa aktif mengajukan pertanyaan, menjawab pertanyaan dan menanggapi. Pemakaian waktu yang belum efektif dan efisien belum bisa diatasi sehingga dalam pembelajaran waktu tidak mencukupi. Untuk meningkatkan hasil yang baik dan bagus maka penelitian dilanjutkan pada siklus II.

\section{Perencanaan Siklus II}

Penggunaan pendekatan dalam pembelajaran tematik terpadu dalam bentuk rencana pelaksanaan (RPP), rencana disusun untuk satu kali pertemuan yaitu 6 x35 menit. Rencana pembelajaran disusun dan dikembangkan berdasarkan kurikulum 2013. Dengan kempetensi dasar dan indikator sebagai berikut:

\section{IPS}

1. Menjalankan ajaran agama dalam berpikir dan berperilaku sebagai penduduk Indonesia dengan mempertimbangkan kelembagaan sosial, budaya, ekonomi, dan politik dalam masyarakat

2. Menunjukkan perilaku santun, toleran dan peduli dalam melakukan interaksi sosial dengan lingkungan dan teman sebaya

3. Mengenal manusia, aspek keruangan, konektivitas antar ruang, perubahan dan keberlanjutan dalam waktu, sosial, ekonomi, dan pendidikan

4. Menceritakan tentang hasil bacaan mengenai definisi ruang, konektivitas antar ruang, perubahan, dan keberlanjutan dalam waktu, sosial, ekonomi, dan pendidikan dalam lingkup masyarakat di sekitarnya

\section{Indikator:}

1. Mengidentifikasi hubungan antara benda-benda dalam kehidupan sehari-hari dengan jenis pekerjaan

2. Menyajikan cerita tentang bacaan mengenai definisi ruang, konektivitas antar ruang, perubahan, dan keberlanjutan dalam waktu, sosial, ekonomi, dan pendidikan dalam lingkup masyarakat di sekitarnya

\section{B. INDONESIA}

1. Mengakui dan mensyukuri anugerah Tuhan yang Maha Esa atas keberadaan lingkungan dan sumber daya alam, alat teknologi modern dan tradisional, perkembangan teknologi, sosial, serta permasalahan sosial

2. Memiliki kepedulian terhadap lingkungan dan sumber daya alam 
melalui pemanfaatan bahasa Indonesia

3. Menggali informasi dari teks cerita petualangan tentang lingkungan dan sumber daya alam dengan bantuan guru dan teman dalam bahasa Indonesia lisan dan tulis dengan memilih dan memilah kosakata baku

4. Menyajikan teks cerita petualangan tentang lingkungan dan sumber daya alam secara mandiri dalam teks bahasa Indonesia lisan dan tulis dengan memilih dan memilah kosakata baku

\section{Indikator:}

1. Menemukan dan menceritakan unsur unsur cerita dari teks cerita petualangan "Semut dan Belalang"

2. Menyajikan teks cerita pertualangan tentang lingkungan dan sumber daya alam

\section{MATEMATIKA}

1. Menerima, menjalankan, dan menghargai ajaran agama yang dianutnya

2. Memiliki rasa ingin tahu dan ketertarikan pada matematika yang terbentuk melalui pengalaman belajar

3. Memahami luas segitiga, persegi panjang, dan persegi

4. Mengembangkan dan membuat berbagai pola numerik dan geometris

\section{Indikator:}

1. Menghitung luas bangun datar menggunakan alat ukur tidak baku

2. Membuat berbagai pola numerik dan geometri

\section{PKN}

1. Menghargai kebersamaan dalam keberagaman sebagai anugerah Tuhan Yang Maha Esa di lingkungan rumah, sekolah, dan masyarakat sekitar

2. Menunjukkan perilaku sesuai dengan hak dan kewajiban sebagai warga dalam kehidupan sehari-hari di rumah sekolah dan masyarakat sekitar

3. Memahami hak dan kewajiban sebagai warga dalam kehidupan sehari-hari di rumah, sekolah, dan masyarakat

4. Melaksanakan kewajiban sebagai warga di lingkungan rumah, sekolah, dan masyarakat

\section{Indikator:}

1. Menjelaskan kewajiban sebagai seorang pekerja di masyarakat.

2. Mendemontrasikan kewajiban sebagai warga di lingkungan rumah, sekolah dan masyarakat

\section{Tujuan Pembelajaran}

1. Dengan menganalisa gambar dan diskusi siswa mampu menjelaskan hubunga antara jenis pekerjaan dan benda yang dihasilkan dengan benar.

2. Dengan bimbingan guru, siswa mampu menyajikan cerita tentang bacaan mengenai definisi ruang, konektivitas antar ruang, perubahan, dan keberlanjutan dalam waktu, sosial, ekonomi, dan pendidikan dalam lingkup masyarakat di sekitarnya dengan benar

3. Dengan eksplorasi, siswa mampu menghitung luas permukaan bangun datar menggunakan satuan tidak baku dengan teliti. 
4. Dengan penjelasan guru, siswa mampu membuat berbagai pola numeric dan geometri dengan tepat

5. Dengan membaca teks cerita petualangan "Semut dan Belalang", siswa mampu menemukan unsur cerita dari teks.

6. Dengan membaca teks "Semut dan Belalang", siswa mampu menjelaskan manfaat bekerja dengan rinci.

7. Dengan membaca teks "Semut dan Belalang", siswa mampu menjelaskan sikap sikap yang harus dimiliki oleh seorang pekerja minimal 3.

8. Dengan penjelasan guru, siswa dapat mendemontrasikan kewajiban sebagai warga di lingkungan rumah, sekolah dan masyarakat dengan tepat.

Untuk mencapai tujuan tersebut, rencana pelaksanaan pembelajaran untuk setiap pertemuan dibagi menjadi tiga tahap yaitu kegiatan awal, kegiatan inti, dan kegiatan akhir. Di mana ke tiga kegiatan ini saling terkait satu sama lain.

\section{Pengamatan}

Hasil pengamatan didiskusikan dengan teman sejawat dan diadakan refleksi untuk perencanaan siklus berikutnya. Obsever mengevakuasi sejauh mana tindakan yang telah dilakukan dalam memecahkan masalah dengan melihat:

1. Menyusun langkah perbaikan pembelajaran.

2. Menentukan alokasi waktu dalam perbaikan pembelajaran
3. Menggunakan bahan atau media perbaikan pembelajaran dan merumuskan tujuan pembelajaran

4. Menentukan cara pengorganisasian siswa agar siswa dapat berpartisipasi dalam perbaikan pembelajaran

5. Melaksanakan pembelajaran yang sesuai dengan tujuan, siswa, situasi dan lingkungan

6. Melaksanakan perbaikan secara individual

7. Memberi petunjuk dan penjelasan yang berkaitan dengan pembelajaran

8. Mendemontrasikan penguasaan materi

9. Mengembangkan siswa untuk berkomunikasi dan bernalar

10. Melaksanakan penilaian selama proses pembelajaran

11. Melaksanakan penilaian pada akhir pembelajaran

Berdasarkan Grafik 4 dapat dilihat bahwa pemahaman konsep belajar, siswa aktif baik mengajukan pertanyaan, menjawab pertanyaan dan memberikan tanggapan. Pengamatan yang dilakukan terhadap guru yaitu penggunaan waktu yang sudah efisien serta cara siswa menguasai materi yang diajarkan sangat bagus.

\section{Refleksi}

Refleksi pada siklus II adalah pada kenyataannya proses pembelajaran tematik yang diinginkan ini sudah tercapai. Guru sebagai fasilitator mampu membuat siswa aktif dalam mengajukan pertanyaan, menjawab pertanyaan dan menanggapinya. Sehingga dengan pembelajaran tematik ini siswa lebih bergairah dan bersemangat dalam belajar. 


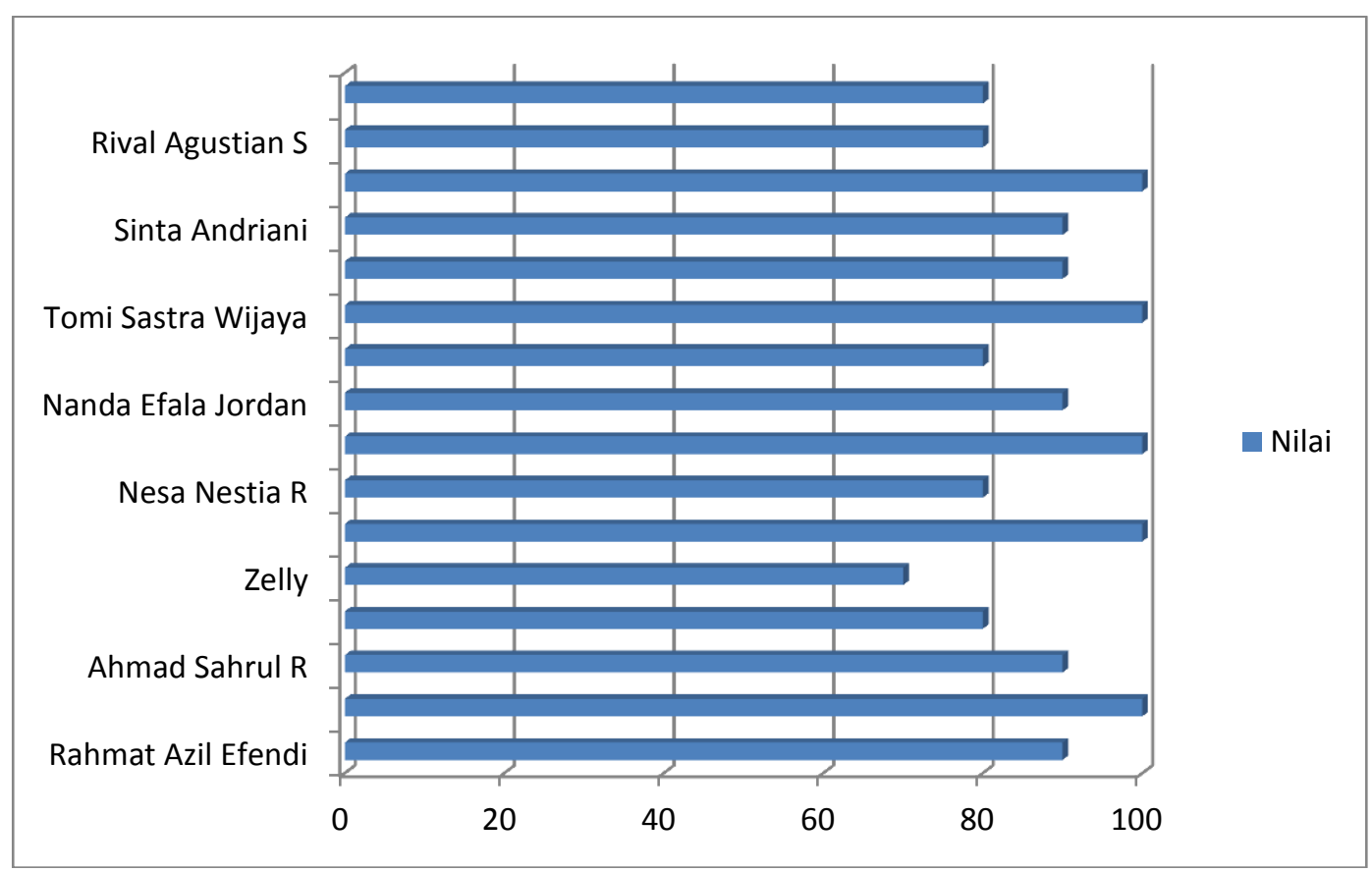

Grafik 3. Hasil Belajar Siswa Siklus II

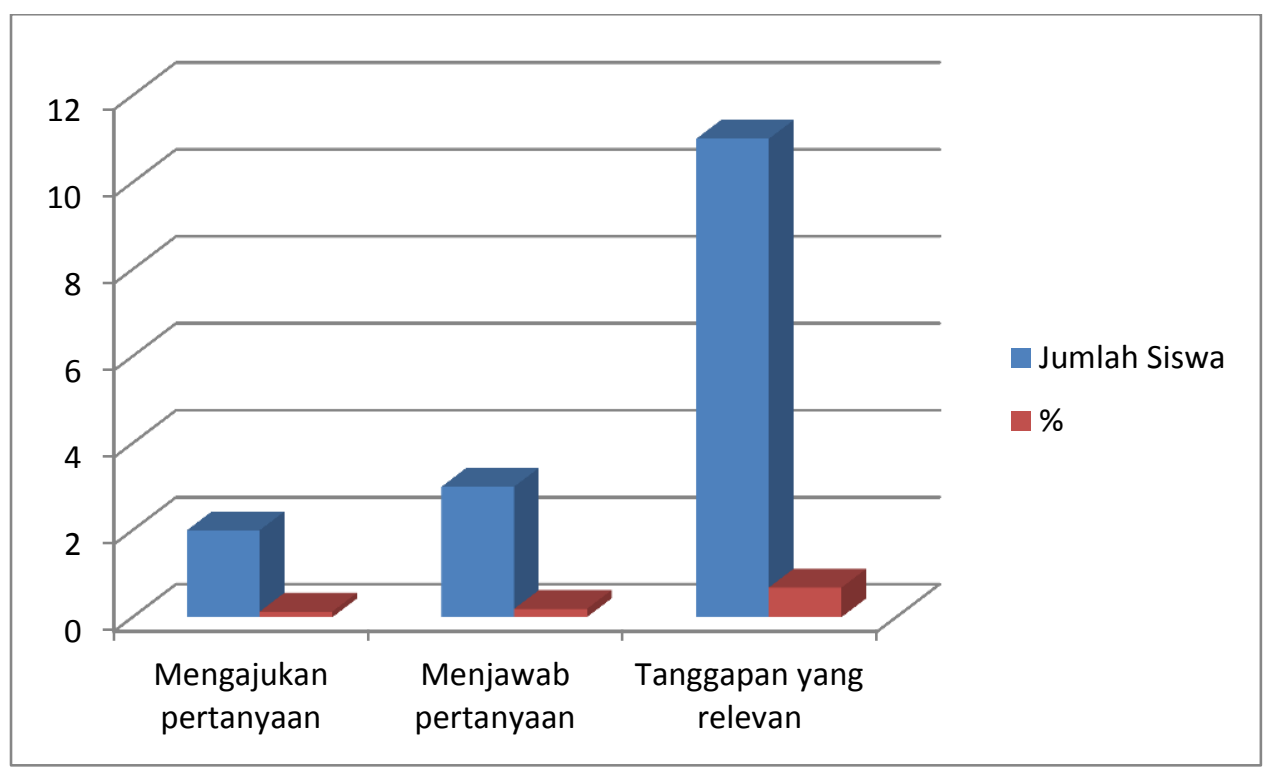

Grafik 4. Aktivitas Belajar Siswa Pada Siklus II 


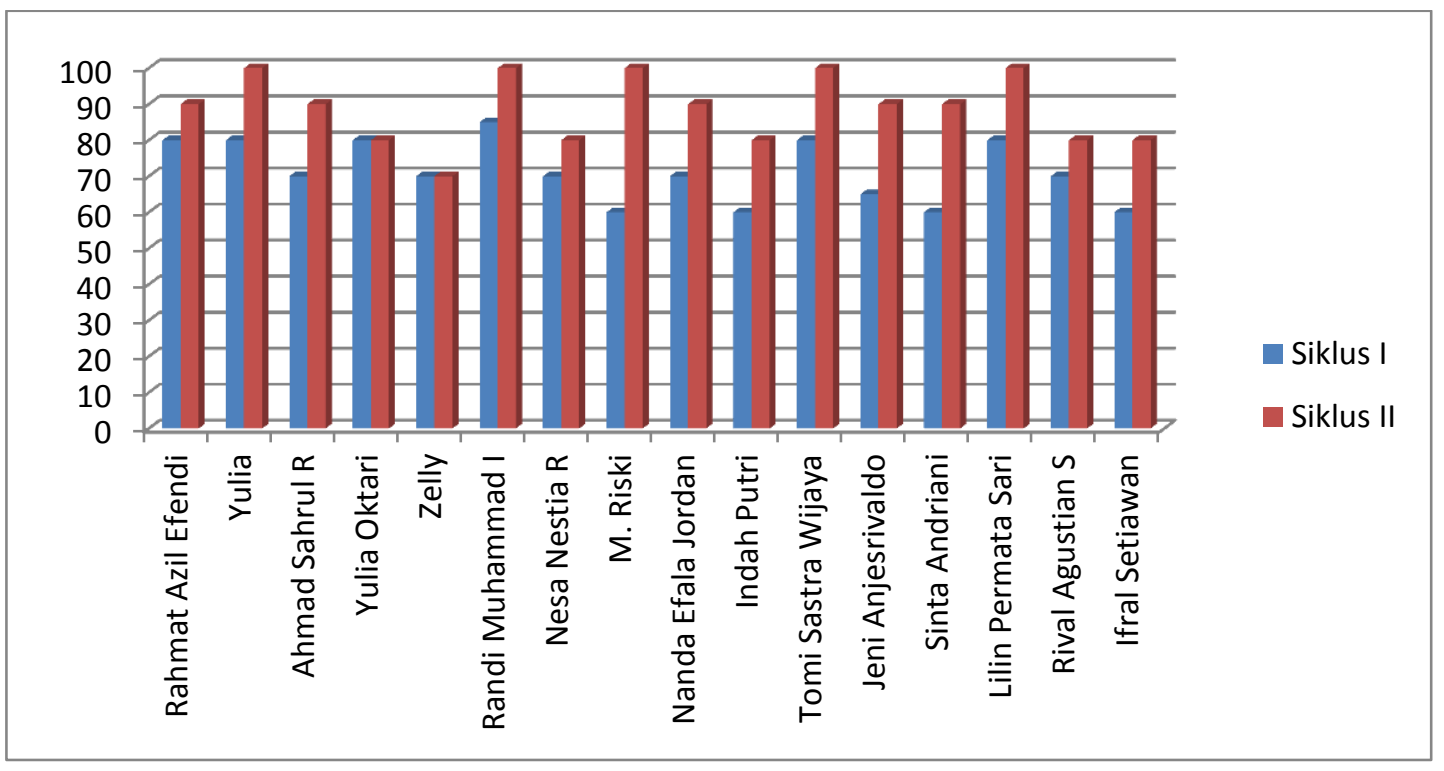

\section{Grafik 5 Hasil Belajar Siswa Pada Siklus I dan Siklus II}

\section{Pembahasan}

\section{Siklus I}

Pada siklus I dilakukan pengamatan oleh teman sejawat pada guru dan siswa yang sedang melaksanakan proses pembelajaran. Guru sudah melaksanakan pembelajaran tematik namun siswa belum aktif mengikutinya. Pada saat pembelajaran berlangsung pun siswa kurang aktif untuk bertanya, mengajukan pertanyaan serta menanggapinya.

Pada akhir pembelajaran guru menjelaskan pelajaran yang menyangkut tema yang dipelajari, serta memberi contoh cara menjawab, mengajukan pertanyaan serta menanggapinya. Siswa mendengarkan penjelasan guru dengan senang dan penuh semangat. Selanjutnya guru memberikan tugas rumah dan menyampaikan pembelajaran untuk siklus II.

\section{Siklus II}

Pada siklus II ini proses pembelajaran tematik masih dilakukan pengamatan oleh teman sejawat pada peneliti sebagai guru dengan siswa dalam melaksanakan pembelajaran. Pembelajaran berlangsung dengan baik, siswa pun lebih aktif dan bersemangat pada saat masing-masing siswa disuruh membaca teks bacaan ke depan kelas.

Pada saat masing-masing siswa disuruh ke depan kelas siswa lebih aktif dan lebih bersemangat lagi dan dalam membaca hasil diskusi kelompok. Dalam proses pembelajaran berlangsung sudah banyak siswa yang bertanya, yang mengajukan pertanyaan dan bahkan ada yang menanggapinya. Pada siklus II ini banyak sekali perubahan dan penigkatan yang signitif dari proses pengajaran guru dan proses pembelajaran dari siswa sehingga dapat dilihat nilai rata-rata dari ketuntasan anak yang mencapai 71.25 pada siklus I, meningkat pada siklus II dengan rata-trata ketuntasan anak mencapai 88.75. dengan demikian penelitian hanya dicukupkan sampai siklus II. 


\section{PENUTUP}

Berdasarkan data hasil penelitian dan pembahasan tentang upaya peningkatan pembelajaran tematik dengan menggunakan pendekatan scientific dapat disimpulkan sebagai berikut:

1. Rencana pembelajaran berdasarkan refleksi awal dan sesuai dengan langkah-langkah pembelajaran yaitu (1) Mengamati, (2) Menanya, (3) Menalar, (4) Mengasosiasikan, (5) Mengkomunikasikan.

2. Pelaksanaan pembelajaran yang telah dilakukan sesuai dengan langkahlangkah pendekatan scientific. Pengamatan dilakukan oleh guru kelas yang bersangkutan dengan mengisi rambu-rambu pengamatan baik untuk aspek guru, dan siswa sehingga apabila terjadi kesalahan dan kekurangan akan terlihat pada lembaran tersebut. Pengamatan dilakukan oleh guru kelas yang bersangkutan dengan mengisi ramburambu pengamatan baik untuk aspek guru dan aspek siswa sehingga apabila terjadi kesalahan dan kekurangan akan terlihat pada lembaran tersebut.

3. Hasil belajar dari aspek hasil belajar siswa pada siklus I dan II diambil dari hasil tes akhir. Dari hasil penelitian siklus I menunjukan ketercapaian yang diperoleh siswa dapat diketahui siklus I adalah 71.25. Sedangkan pada siklus II dapat diketahui nilai siswa adalah 88.75.

Berdasarkan kesimpulan yang telah diuraikan di atas, maka peneliti mengajukan beberapa saran sebagai berikut:

1. diharapkan guru membuat perencanaan yang matang sesuai dengan model pembelajaran yang diterapkan, dan memahami langkahlangkah pembelajaran akan dilaksanakan.

2. diharapkan guru mampu melaksanakan kegiatan belajar mengajar sesuai dengan rancangan yang sudah dibuat sebelumnya. Dalam menerapkan pembelajaran dengan menggunakan Media dan guru harus benar-benar memahami langkah-langkahnya, dan dapat mengelola waktu seoptimal mungkin. Peran guru sebagai fasilitator dan motivator sangat penting.

3. Bagi guru hendaknya pembelajaran dengan menggunakan pendekatan scientific ini dapat dijadikan sebagai salah satu alternatif dalam pembelajaran tematik karena mampu meningkatkan hasil belajar siswa dalam pembelajaran tematik. Agar hasil belajar yang diharapkan dapat meningkat, sebaiknya guru tidak hanya melakukan penilaian hasil saja, tetapi juga melakukan penilaian proses untuk melihat keaktifan dan kemampuan siswa dalam menemukan jawaban dari suatu permasalahan yang sudah dirumuskan.

\section{UCAPAN TERIMA KASIH}

Terbitnya tulisan ini tidak terlepas dari bantuan berbagai pihak, untuk itu penulis ucapkan terima kasih kepada Pihak STKIP PGRI Sumatera Barat 
khususnya pengelola jurnal Pelangi yang telah memberikan kesempatan kepada penulis untuk publikasi di Jurnal Pelangi. Penulis juga berterima kasih kepada para penyumbang sumber inspirasi yang telah memberikan inspirasi bagi penulis untuk mengutip atau menggunakan tulisannya sebagai bahan referensi.

\section{DAFTAR PUSTAKA}

Depdiknas, (2006). Kurikulum Tingkat Satuan Pendidikan Jenjang Pendididkan Dasar dan Menengah. Jakarta: BSNP

Emzir.(2011). Metodologi Penelitian Pendidikan Kuantitatif dan Kualitatif. Jakarta: PT Raja Grafindo Persada.

Emzir. 2010. Metodologi Penelitian Pendidikan Kuantitatif dan Kualitatif. Jakarta: Rajawali Press

Hudson, D. (1996). Laboratory work as scientific method: Three decades of confusion and distortion. Journal of Curriculum Studies, 28(2), 115-135.

Kemdikbud. (2013). Pengembangan Kurikulum 2013. Paparan Mendikbud dalam Sosialisasi Kurikulum 2013. Jakarta :Kemdikbud
Kunandar. (2007). Langkah Mudah Penelitian Tindakan Kelas Sebagai Pengembangan Profesi Guru. Jakarta : PT Raja Grafindo Persada

Kusumah, Wijaya ,dkk.2011. Mengenal Penelitian Tindakan Kelas. Jakarta: PT. Indeks

Kemendikbud. 2013. Implementasi Pembelajaran Tematik Terpadu . Jakarta

Kusnandar. 2007. Guru Profesional Implementasi Kurikulum Tingkat Satuan Pendidikan (KTSP) dan Sukses dalam Sertifikasi Guru. Jakarta: Rajawali Press

Lazim M. (2013). Penerapan Pendekatan Saintifik Dalam Pemeblajaran Kurikulum 2013. Jurnal.

Rusman. 2010. Model-Model pembelajaran. Jakarta: Rajawali Press.

Trianto. 2011. Desain Pengembangan Pembelajaran Tematik Bagi Anak Usia Dini TK/RA \& Anak Usia Kelas Awal SD/MI . 2010. Mengembangkan Model Pembelajaran Tematik. Jakarta: Prestasi Pustaka

Varelas, M and Ford M. (2009). The scientific method and scientific inquiry: Tensions in teaching and learning. USA: Wiley InterScience. 